Corresponding Author: Tutut Chusniyah; email:

tutut.chusniyah.fppsi@um.ac.id

Dates

Published 28 January 2022

Publishing services provided by Knowledge E

(c) Intan Sarah Cahyanya Brillyanda et al. This article is distributed under the terms of the Creative Commons.

Attribution License, which permits unrestricted use and redistribution provided that the original author and source are credited.

Selection and Peer-review under the responsibility of the ICoPsy Conference Committee.

\section{Attitude Towards Life and Spiritual Health as Predictors of Psychological Well-Being in State University of Malang Students Who Work Part-Time}

\section{Intan Sarah Cahyanya Brillyanda ${ }^{1}$, Tutut Chusniyah ${ }^{1^{*}}$, Gary Dwi Primastio ${ }^{1}$, and Murfiah Dewi Wulandari²}

${ }^{1}$ Faculty of Psychology, State University of Malang, Malang, Indonesia

${ }^{2}$ University of Muhammadiyah Surakarta, Surakarta, Indonesia

ORCID

Tutut Chusniyah; https://orcid.org/0000-0002-2203-7627

https://orcid.org/0000-0001-8014-7246

Abstract. The objectives of this study were to: (i) explore the psychological well-being of part-time working students at the State University of Malang; (ii) examine the life attitude of these students; (iii) investigate their spiritual health; and (iv) determine whether life attitude and spiritual health can be used to predict psychological well-being of part-time working students at the State University of Malang. This was a quantitative study, which used a descriptive design and was conducted with 85 students recruited through purposive sampling. The instruments used included a psychological well-being scale, life attitude scale, and spiritual health scale. Data were analyzed descriptively, and inferential analysis was carried out using Product Moment. The findings indicated that there was an impact between the three variables. Thus, the results showed that: (i) most of the students had moderate psychological well-being, life attitude and spiritual health; and (ii) there was a significant association between psychological well-being and spiritual health $(p=0.035)$, but not between psychological well-being and life attitude $(p=0.726)$. The results suggest that, for a student with a part-time job to have good psychological well-being, they need to enhance their positive life attitude and positive spiritual health.

Keywords: psychological well-being, life attitude, spiritual health, part-time work

\section{Introduction}

Entering adulthood is one of the stages that humans go through. Adult age indicates that someone is taking on heavier responsibilities, such as completing a busy schedule of activities, managing time and money, determining life goals, and other activities that require self-responsibility. This is a natural thing felt by individuals who are experiencing a period of transition to adulthood. This transition period can be experienced by

\section{G OPEN ACCESS}


Students have various types of needs that are increasing and crucial, one of which is the need to support their education, such as tuition fees (Uang Kuliah Tunggal/UKT), training/seminar fees, research/research costs, study field practice fees, costs to buy books, photocopy fees, internet fees, and various other costs to meet the demands of education. In addition, there are still student living expenses such as pocket money and transportation fees. Not all students have enough money to pay for all their needs and not all students have the satisfaction of the pocket money given by their parents. Therefore, as a way out of this problem, students decide to do part-time work as a solution because this type of work does not take too much time.

There are reasons that make students decide to work part-time. As stated by Daulay, students who work part time are motivated by economic problems, filling their spare time, living independently, and seeking experience [1]. Meanwhile, according to Jacinta, what underlies a student to work includes financial needs, social-relational needs, and self-actualization needs [1].

Every job has different difficulties, challenges, threats, and workloads to meet the needs. Saturation and tension that occurs protracted can cause stress. A survey result from the Student Affairs of the University of Buffalo stated that stress is often experienced by working students [2]. They sometimes feel academic pressure, adjust to a new environment, or develop friendships with other individuals. With a busy schedule, students who work part-time have a susceptibility to stress. This stress can create challenges for students who work part-time so that it can cause emotional problems, such as feeling inferior to others, not being able to think well, worrying too much, feeling that life is worthless, and feeling anxious for no reason [3]. Psychological well-being, a positive attitude towards life, and good spiritual health are needed so that students can carry out their roles well and control themselves from problems that can create stress.

\section{Literature Review}

According to Schultz, psychological well-being is a positive function in individuals, where this positive function can determine the direction or goals that healthy individuals are trying to achieve [4]. Psychological well-being is positive mental health [5]. Positive mental health is the absence of psychological disorders, such as depression, anxiety, and other disorders. In other words, research shows that psychological well-being is a distinct, multidimensional concept which develops through a combination of emotion regulation, personal characteristics, identity, and life experiences [5]. From some of the 
opinions above, it can be concluded that psychological well-being is a condition in which individuals are free from psychological disorders so that they can function properly.

Ryff [6] stated that psychological well-being has aspects consisting of self-acceptance, positive relations with others, autonomy, personal growth, environmental mastery, and purpose in life. Self-acceptance is positive thinking about oneself, the ability to know one's own qualities and accept it, positive feelings, and acceptance of the past [6]. Purpose in life is to establish positive relationships with others in the form of warmth, satisfaction, empathy, understanding, caring for the well-being of others, and trust in others are essential components in developing trust and lasting relationships with others [6]. Autonomy is the regulation of one's behavior through the locus of control in oneself [6]. Personal growth is the ability to develop and expand oneself to become a fully functioning person, achieve self-actualization, and achieve goals [6]. Environmental mastery is the ability to control and regulate the environment so that it is in accordance with personal contexts and values, being able to choose or create environmental contexts that are in accordance with personal values [6]. Purposes in life are goals in life that should be owned as a mover, a feeling of direction, meaning to the past and present, having a purpose in life [6].

Attitudes towards life are attitudes that contain comprehensive values and perspectives that individuals hold on the way of life and life itself, old age, illness, and death [7]. According to Reker \& Peacock [8], attitudes towards life have 7 aspects, namely: (i) life purpose or the spirit of an individual's life to pursue life goals; (ii) existential vacuum or the emptiness of existence that is felt by individuals because of the absence of life goals; (iii) life control or individual freedom to take responsibility for their lives; (iv) death acceptance or the absence of anxiety about death; (v) will to meaning or the desire to find meaning in life; (vi) goal-seeking or the desire to seek goals and life experience; and (vii) future meaning or acceptance of the potential for the future, fulfillment of life for the future, and positive expectations regarding the individual with his future.

According to Young, spiritual health is the interconnectedness of the body, mind, and spirit in the context of inner peace, and relating to others and to nature [9]. According to Fisher, there are several aspects of spiritual health [10]. These aspects are personal domain, communal domain, environmental domain, and transcendental domain. Personal domain is how a person relates to himself in terms of appreciating meaning, purpose, and values in his life. Self-awareness is the directing energy in the search for identity and self-worth. Communal domain is the quality and depth of interpersonal relationships between self and others, relationships related to morality, culture, and religion in a person. The environmental domain is a person's concern for 
the environment and a sense of wanting to care for the environment. Transcendental domain is one's relationship with God Almighty. This includes faith in God, admiration, and worship of God.

\section{Method}

\subsection{Research Design}

This study used a quantitative approach as an effort to test the hypotheses that have been prepared. In this study there were three variables, namely the independent variable and the dependent variable. The independent variables were attitudes towards life (X1) and spiritual health (X2), while the dependent variable was psychological wellbeing $(Y)$. The purpose of this study was to determine attitudes towards life and spiritual health as predictors of psychological well-being in State University of Malang students who work part time.

\subsection{Population and Sample}

The total population used in this study is unknown. The sampling technique used is the accidental sample. The population criteria in this study are: (i) active students at State University of Malang; and (ii) have a part time job.

\subsection{Research Instrument}

Research instrument is a tool used to collect data or information that is useful to answer research problems. This study uses three types of instruments, namely the psychological well-being scale, the attitude towards life scale, and the spiritual health scale. The scales used in this study are the Likert scale. The psychological well-being scale used is a measuring tool developed by Ryff [11], which consists of 18 items based on 6 aspects. The attitude towards life scale used is a measuring tool developed by Gary T. Reker and Edward J. Peacock [8], which consists of 44 items based on 7 aspects. The spiritual health scale was developed by John W. Fisher [10], which consists of 20 items based on 4 aspects. 


\subsection{Validity Test}

The psychological well-being scale contains 18 items consisting of 12 favorable statements and 6 unfavorable statements. Based on the calculation of the validity of the psychological well-being of 18 items, 6 items were declared invalid/failed and 12 items were declared valid. The attitude towards life scale contains 44 items consisting of 37 favorable statements and 7 unfavorable statements. Based on the calculation of the validity of attitudes towards life from 44 items, 16 items were declared invalid/failed and 28 items were declared valid. There are 2 items that go through the wording process or changing words. After going through the validity test after the try out, the items on the attitude towards life scale are reduced from 44 items to 30 items. Based on the calculation of the validity of the attitude towards life from 30 items, it was found that 2 items were declared invalid/failed and 28 items were declared valid. The spiritual health scale contains 20 favorable items. Based on the calculation of the validity of spiritual health from 20 items, the results obtained are 3 items are declared invalid/failed and 17 items are declared valid.

\subsection{Reliability Test}

Reliability test in this study used Alpha Chronbach. From the results of the psychological welfare reliability test on 12 items which were declared valid, the reliability coefficient value was 0.723 . The value of the reliability coefficient on the 28 valid items on the attitude to life scale is 0.748 . While the coefficient value on 17 valid items in the spiritual health scale is 0.753 .

\subsection{Data Analysis}

Data analysis used in this research is descriptive analysis technique, normality test, linearity test, and hypothesis testing. Sugiyono [12] stated that descriptive analysis technique is an analytical technique carried out to determine the value of independent variables, either one or more (independent) variables without making comparisons, or connecting with other variables. Normality test is used to determine whether the two variables have a normal distribution or not so that it can be used in parametric statistics. The normality test has data distribution which is carried out using the KolmogorovSmirnov or KR-S test with the help statistical software. The criteria used to determine whether the data distribution is normal or not, namely if $p>0.05$ then the data 
distribution can be declared normal. However, if $p<0.05$ then the data distribution can be declared abnormal [13].

The linearity test is used to determine whether the two data from the variables are linear or not so that the conclusions drawn do not deviate from the truth. Data can be said to be linear if it has a $p$ value $<0.05$. While the data can be said to be non-linear if $p>0.05$. Hypothesis testing in this study uses simple regression analysis.

\section{Result and Discussion}

\subsection{Descriptive Test}

Based on the results of descriptive statistical calculations, the data obtained get the average score of the total psychological well-being of 85 respondents is 53.76 with the number of statement items as many as 12 items. The lowest value of the total score of psychological well-being is 39 while the highest score of the total score of psychological well-being is 66 with a standard deviation score of 5.11. State University of Malang students who work part-time have psychological well-being in the low-level category as many as 9 people (9\%), moderate-level psychological well-being as many as 62 people (62\%), and the high category as many as 14 people (14\%). This shows that the majority of respondents have a moderate level of psychological well-being.

Based on the results of descriptive statistical calculations, the data obtained get the average score of the total attitude towards life of 85 respondents is 139 with the number of statement items as many as 30 items. The lowest value of the total score of attitudes towards life is 95 while the highest value of the total score of attitudes towards life is 165 with a standard deviation score of 12.63. State University of Malang students who work part-time have attitudes towards life in the low-level category as many as 13 people (13\%), attitudes towards life in the moderate category as many as 64 people (64\%), and the high category as many as 8 people (8\%). This shows that the majority of respondents have a moderate level of attitude towards life.

Based on the results of descriptive statistical calculations, the data obtained get the average score of the total attitude towards life of 85 respondents is 84.41 with the number of statement items as many as 17 items. The lowest score of the total spiritual health score was 51 while the highest score of the total spiritual health score was 98 with a standard deviation score of 9.06. State University of Malang students who work part-time have spiritual health in the low level category as many as 10 people (10\%), moderate level of spiritual health as many as 57 people (57\%), and high category as 
TABLE 1: Residual normality test results.

\begin{tabular}{l|l|l} 
& Significance & Conclusion \\
Residual & 0.200 & Normal
\end{tabular}

TABLE 2: Linearity test results.

\begin{tabular}{|c|c|c|c|}
\hline Variable & Significance & Remarks & Conclusion \\
\hline $\begin{array}{l}\text { Psychological Well- } \\
\text { Being }(X) \text { and Atti- } \\
\text { tudes to Life }(Y)\end{array}$ & 0.726 & Sig. $>0.05$ & Linear \\
\hline $\begin{array}{l}\text { Psychological Well- } \\
\text { Being }(X) \text { and Spiri- } \\
\text { tual Health }(Y)\end{array}$ & 0.035 & Sig. $>0.05$ & Linear \\
\hline
\end{tabular}

many as 18 people (18\%). This shows that the majority of respondents have a moderate level of spiritual health.

\subsection{Normality Test}

Based on table 1, it can be seen that the significance of the three variables is 0.200 . The significance value greater than 0.05 then the data is said to have a normal distribution.

\subsection{Linearity Test}

Based on table 2, the results of the analysis show that the p-value of the psychological well-being and attitude toward life variable is $0.726(p>0.05)$, while the analysis of the psychological well-being and attitude toward life variable is 0.035 ( $p>0.05)$. Thus, it can be said that these variables have a linear relationship.

\subsection{Hypothesis Test}

From table 3 , it is known that the value of $R$ is 0.595 . This figure means that the value of the correlation/relationship is $59.5 \%$. While for $\mathrm{R}$ square is 0.354 . This shows that the independent variables, namely attitudes towards life and spiritual health, contribute to the psychological well-being variable by $35.4 \%$, from this the $\mathrm{R}$ square value of $35.4 \%$

TABLE 3: Simple linear regression results.

\begin{tabular}{|l|l|l|l|}
\hline $\mathbf{R}$ & R Square & $\begin{array}{l}\text { Std. Error of the } \mathbf{p} \text { value } \\
\text { Estimate }\end{array}$ \\
\hline 0.595 & 0.354 & 4.164 & $p<0.05$ \\
\hline
\end{tabular}


TABLE 4: Attitudes to life and spiritual health as predictors of psychological well-being.

\begin{tabular}{l|l|l} 
Variable & Sig. & p value \\
\hline Attitude towards Life (X1) & 0.000 & $<0.05$ \\
\hline Spiritual Health $(\mathbf{X})$ & 0.121 & $>0.05$
\end{tabular}

is included in the small category. While the remaining $64.6 \%$ is influenced by other unknown variables and is not included in this regression analysis.

From table 4, it is known that the attitude towards life variable (X1) significantly contributes to the psychological well-being variable $(\mathrm{Y})$, while the spiritual health variable $(\mathrm{X} 2)$ contributes to the psychological well-being variable $(Y)$, but is not significant. The conclusion of this hypothesis test is that attitudes toward life and spiritual health are predictors of psychological well-being.

\subsection{Discussion}

\subsubsection{Overview of the Psychological Wel-Being of State University of Malang Students who Work Part Time}

In this study, there were 62 respondents who had a moderate level of psychological well-being. Aspects of psychological well-being that are not good for 62 respondents are aspects of personal growth, purpose in life, and self-acceptance because the lowest scores are found in these three aspects. Some respondents had difficulty establishing warm and trusted relationships with others and were not happy with their lives. In addition, some respondents did not have clear goals for their future. According to Ryff [6], the purpose of life is an important part of fighting for success, thereby eliminating the sense of hopelessness experienced by individuals. By having a purpose in life, individuals can have a more meaningful life.

\subsubsection{Overview of Attitudes towards the Life of State University of Malang Students who Work Part Time}

According to Frankl attitude towards life is defined as a state of individual subjective satisfaction, which results in meaningful activity [14]. In short, an attitude towards life is an individual's attitude towards the experiences of his life. Awareness of life comes from the perspective of existential psychology, but globally there is a cognitive perspective on attitudes towards life. Reker [7] suggests that existential psychology assumes that 
being human means that individuals must make decisions, to pursue goals and act. Thus, attitudes towards life are closely related to the meaning of life.

Based on the research, there are 64 respondents from State University of Malang students who work part-time with a moderate attitude towards life. The aspect of death acceptance is the aspect with the lowest score. This could be due to cultural bias. The item contained in the death acceptance aspect is about the fear of death.

\subsubsection{Overview of the Spiritual Health of State University of Malang Students who Work Part Time}

According to Young, spiritual health is the interconnectedness of the body, mind, and spirit in the context of inner peace, and relating to others and to nature [9]. In this study, there were 57 respondents who had a moderate level of spiritual health. The aspect that has the lowest score is the personal and transcendental aspect, the personal aspect is the individual's relationship with oneself, while the transcendental aspect is the relationship between the individual and God. Some individuals feel that their lives are meaningless and do not feel peaceful. This can happen because the individual does not appreciate his life so that he does not try to make his life meaningful. One aspect of spiritual health is a relationship with oneself. Relationship with self includes understanding individual identity and positive attitude towards oneself so that it can be manifested in self-confidence. With a harmonious relationship with yourself, it can give a sense of peace.

\subsubsection{Attitudes towards Life as Predictors of Psychological Well-Being in State University of Malang Students who Work Part Time}

The problem with attitude towards life is existence, which is related to Frankl's theory which focuses on human existence and human efforts to have a meaningful existence [7]. As Frankl means that if a person does not seek meaning in his life, he will lose his well-being [7]. The data obtained from this study indicate that attitudes towards life contribute significantly to psychological well-being. The significance obtained is $0.000<0.005$. This is in line with Emmons' concept about meaning in life, where the goals possessed by people who need an awareness of the meaning of life can be the foundation for well-being. In other words, a positive attitude towards life will encourage individuals to have better psychological well-being. 


\subsubsection{Spiritual Health as a Predictor of Psychological Well-Being in State University of Malang Students who Work Part Time}

The data obtained from this study indicate that spiritual health contributes to psychological well-being, but it is not significant because the significance is $0.121>0.005$. Spiritual health contributes to psychological well-being in line with Buck's concept. Buck [7] argues that spirituality multiplies the experience of going beyond oneself, and connecting with other people, nature, and God. Coward argues that transcendence removes emotional wounds and the wounds of death, and thus becomes a new promise for life purpose and acceptance of the unavoidable [7].

\subsubsection{Attitudes to Life and Spiritual Health as Predictors of Psycholog- ical Well-Being in State University of Malang Students who Work Part Time}

Based on the results of the calculation test using simple linear regression analysis in this study, it can be said to be quite influential. The results of simple linear regression analysis on three variables, namely attitudes towards life and spiritual health on psychological well-being are $\mathrm{R}$ 0.595, which means that these three variables have a significant influence. This can be strengthened by research from Reker \& Peacock [8], which is known that the problem of attitude towards life is existence, which has a relationship with Frankl's theory which focuses on human existence and human efforts to have a meaningful existence. By having a meaningful existence, human life will be more prosperous [7]. According to Gawain, good spiritual health can help individuals to purify their mind. Therefore, if the individuals can calm himself and purify their mind in a calm state, the conclusion is that attitude towards life and spiritual health are predictors of psychological well-being [7].

\section{Acknowledge, Funding \& Ethics Policies}

The authors would like to thank the Faculty of Psychology of the State University of Malang for supporting this research funding from the beginning until the end, also appreciate every participant that has been involved with this research so that it is completed. 


\section{References}

[1] Mardelina E, Muhson A. MAHASISWA BEKERJA DAN DAMPAKNYA PADA AKTIVITAS BELAJAR DAN PRESTASI AKADEMIK. JE. 2017 Oct 1;13(2):201. doi: 10.21831/economia.v13i2.13239

[2] Puspitadewi NWS. Hubungan antara Stress dan Motivasi Kerja pada Mahasiswa yang Bekerja Paruh Waktu. JPTT. 2012 Feb 19;2(2):126. doi: 10.26740/jptt.v2n2.p126-134

[3] Udhayakumar P, Illango P. Psychological wellbeing among college students. April 2018. 2017;3(2):79-89.

[4] Ramadhani T, Djunaedi D, Sismiati S. A. KESEJAHTERAAN PSIKOLOGIS (PSYCHOLOGICAL WELL-BEING) SISWA YANG ORANGTUANYA BERCERAI (Studi Deskriptif yang Dilakukan pada Siswa di SMK Negeri 26 Pembangunan Jakarta). insight. 2016 Jan 30;5(1):108. doi: 10.21009/INSIGHT.051.16

[5] Edwards DJ. Sport psychological skills training and psychological well-being in youth athletes [PhD Thesis]. [Pretoria]: University of Pretoria; 2008.

[6] Ryff CD. Happiness is everything, or is it? Explorations on the meaning of psychological well-being. Journal of Personality and Social Psychology. 1989;57(6):1069-81.doi: 10.1037/0022-3514.57.6.1069

[7] Chou M-J, Tsai S-S, Hsu H-M, Wu H-T. Research on correlation between the life attitude and well-being-with spiritual health as the mediator. European Journal of Research in Social Sciences Vol. 2016;4(3):76-88.

[8] Reker GT, Peacock EJ, Wong PTP. Meaning and Purpose in Life and Wellbeing: a Life-span Perspective. Journal of Gerontology. 1987 Jan 1;42(1):44-9. doi: 10.1093/geronj/42.1.44

[9] Jaberi A, Momennasab M, Yektatalab S, Ebadi A, Cheraghi MA. Spiritual Health: A Concept Analysis. J Relig Health. 2019 Oct;58(5):1537-60. doi: 10.1007/s10943-0170379-z

[10] Fisher J. Development and Application of a Spiritual Well-Being Questionnaire Called SHALOM. Religions. 2010 Dec 9;1(1):105-21. doi: 10.3390/rel1010105

[11] Ryff CD. Psychological Well-Being in Adult Life. Curr Dir Psychol Sci. 1995 Aug;4(4):99-104. doi: 10.1111/1467-8721.ep10772395

[12] Sugiyono S. Metode penelitian administrasi. 5th ed. Jakarta: Alfabeta; 2008. 334 p.

[13] Gunawan J. ENSURING TRUSTWORTHINESS IN QUALITATIVE RESEARCH. Belitung Nurs J. 2015 Dec 7;1(1):10-1. doi: 10.33546/bnj.4 
[14] Klamut R. Assessment of decisions in the context of life attitudes. Journal for Perspectives of Economic Political and Social Integration. 2012 Jan;18(1-2):159-176. doi: $10.2478 / \mathrm{v} 10241-012-0031-5$ 